\title{
REVITALIZING LOCAL WISDOM IN COMMITTING RADICALISM IN ACEH
}

\author{
Happy Saputra \\ UIN Ar-Raniry Banda Aceh \\ Email: happy.saputra@ar-raniry.ac.id \\ Mahdalena Nasrun \\ UIN Ar-Raniry Banda Aceh \\ Email: mahdalena.nasrun@ar-raniry.ac.id
}

\author{
Muhammad Anzaikhan \\ IAIN Langsa Banda Aceh \\ Email: m.anzaikhan@iainlangsa.ac.id
}

\begin{abstract}
Local wisdom is known as a cultural asset that develops in an area, all policies and customs that play a role in Aceh will become a culture that is respected and appreciated in Aceh. In its development, local wisdom is very influential in protecting people's thoughts, including the seeds of radicalism. The existence of radicalism in Aceh was most evident during the conflict between the Republic of Indonesia and the separatist movement in Aceh. After the peace period of the MOU Helsingki took place, radicalism in Aceh did not occur openly. Only ripples of thought trying to incite from within the disapproval of the current government. You could say, the turmoil arose because of the influence of political color, where the current population of Aceh is quantitatively more inclined to the failed presidential candidate. The problem raised in this study is how to revitalize the values of Aceh's local wisdom which are threatened with fading due to the globalization of foreign cultures. This research design uses qualitative with reference sources based on literature and field studies. The analysis technique is descriptive. The findings of this study are that local wisdom is ideal in countering the existence of radicalism in Aceh through the media meuseumeuraya, tengku authorities, implementing the values of 'hadih madja', subdistrict da'i programs, and so on. In conclusion, strengthening local wisdom in Aceh is very urgent because the character of the Acehnese people respects traditional values and authority more than the government authority.
\end{abstract}

Keywords: revitalization, local wisdom, radicalism

\begin{abstract}
Abstrak: Kearifan lokal dikenal sebagai aset budaya yang berkembang di suatu daerah, semua kebijakan dan kebiasaan yang memainkan peran keacehan akan menjadi suatu kultur yang dihormati dan dihargai di Aceh. Pada perkembangannya kearifan lokal sangat berpengaruh dalam memproteksi pemikiran masyarakat termasuk bibit-bibit radikalisme. Eksistensi radikalisme di Aceh paling kentara terjadi pada masa konflik antara NKRI dan gerakan sparatis di Aceh. Setelah masa damai MOU Helsingki terjadi, radikalisme di
\end{abstract}


Aceh tidak terjadi secara terbuka. Hanya riak-riak pemikiran yang mencoba menghasut dari dalam tentang ketidaksetujuan terhadap pemerintahan saat ini. Bisa dibilang, gejolak itu muncul karena pengaruh warna politik yang mana saat ini penduduk Aceh secara kuantitas lebih condong pada calon Presiden yang gagal terpilih. Adapun masalah yang diangkat dalam penelitian ini adalah bagaimana merevitalisasikan nilai-nilai kearifan lokal Aceh yang terancam pudar akibat serangan globalisasi budaya luar. Design penelitian ini menggunakan kualitatif dengan sumber referensi berbasis kajian pustaka dan lapangan. Teknik analisis berupa deskriptif. Temuan dari penelitian ini adalah kearifan lokal sangat ideal dalam menangkal eksistensi radikalisme di Aceh melalui media meuseumeuraya, otoritas tengku,implementasi nilai hadih madja, program da'i kecamatan dan lain sebagainya. Kesimpulannya, penguatan kearifan lokal di Aceh sangat urgen karena karakter masyarakat Aceh lebih menghormati nilai dan otoritas adat dibanding otoritas pemerintah.

Kata-kata kunci: revitalisasi, kearifan lokal, radikalisme

\section{Introduction}

Local wisdom in Aceh is not only limited to custom but has also become a unit that has penetrated into various aspects. For example, according to historical researchers, the system of government in Aceh is based on the Qanun Asyi (meukuta alam custom), a law made during the reign of Sultan Iskandar Muda (1607-1675 AD). This law regulates the government system from the lowest level (gampong) to the highest level, namely the sultanate. This system was valid until the colonial era came and even entered the independence period ${ }^{1}$. This is one proof that local wisdom in Aceh plays a vital role even in today's executive orientation.

Even though Aceh's local wisdom has been neglected by the policies of the central government, the substance of Acehnese values will never fade. History has become evident, in the era after the formation of the State of Indonesia, precisely when political and social changes were so significant in 1979, there was a conversion of traditional institutions during the Aceh kingdom. As a result, the gampong government in Aceh, the nagari in West Sumatra, and several other customary systems in Indonesia were abolished and replaced with a village government system².

When it comes to radicalism, Aceh is actually not an area that is always conducive, various prolonged and ongoing conflicts often color the history of Aceh. The people of Aceh struggled to demand their rights which were not properly granted by the central government at that time ${ }^{3}$. The phenomenon and dark history continued to occur until a bright spot came through the peace agreement between Aceh and the Republic of Indonesia at the MoU Helsingki in 2005.

If analyzed further, almost all vertical and horizontal conflicts that occurred in Aceh could be resolved peacefully. As evidence is; first, the struggle of DI/TII Teungku Daud Beureueh was resolved peacefully known as the Aceh People's Harmony Deliberation, the culmination of a peaceful customary settlement was held on 18-21 December 1962 in Blang Padang, Banda Aceh ${ }^{4}$ Second,

${ }^{1}$ Muslim Ibrahim, Langkah-Langkah Penerapan Syariat Islam di Aceh dalam Lahmuddin Nasution (et. al.), Penerapan Syari'at Islam di Indonesia: Antara Peluang dan Tantangan (Jakarta: Globalmedia Cipta Publishing, 2004), p. 178.

${ }^{2}$ Research team PKPM, Penerapan Alternatif Dispute Resolution Berbasis Hukum Adat Pada Lembaga Keujreun Blang di Kabupaten Aceh Besar (Banda Aceh: BRR Sarpras Hukum dengan PKPM, 2007), p. 3.

${ }^{3}$ C. Van Dijk, Rebellion Under the Banner of Islam: The Darul Islam in Indonesia (The Hague: Martinus Nijhoff, 1981). p. 22.

${ }^{4}$ A. Hasjmy, et al., 50 Tahun Aceh Membangun (Medan: MUI Provinsi NAD, 1995), p. 192 and Badruzzaman Ismail, Pola-Pola Penyelesaian Pelanggaran HAM: Pendekatan Adat Sebagai Aspek 
the Cumbok between the ulama and the uleeb alang (aristocracy) ended peacefully known as the lamteh pledge, 1946; this is different from the DI/TII cases in South Sulawesi led by Kahar Muzakkar and West Java led by Kartosuwirjo. These two cases were resolved with a militaristic approach. In fact, the two leaders were arrested and then killed.

Third, the Free Aceh Movement (GAM) which fought for more than 30 years against the Jakarta government ended with the Helsinki MoU peace, 2005; fourth, the conflict between students and students of Central Aceh and South Aceh also ended in peace at the Harapan Bangsa Stadium, 2013. The conflict which then always ended in peace would not have been possible if there were no strong cultural roots in the form of local wisdom of the Acehnese people 5 .

\section{Definition of Revitalization}

Revitalization is an effort to revitalize a discourse or term that was once vital/lived, but then suffered a setback/degradation. The scale of revitalization has macro and micro levels. The revitalization process includes many aspects such as improving physical aspects, economic aspects, and social aspects, even spiritual aspects. The revitalization approach must be able to recognize and utilize the potential of the environment where the object is studied (history, meaning, uniqueness of the location, and image of the place $)^{6}$.

Revitalization itself is not something that is only oriented towards solving the empirical dimension alone but must also be equipped with increasing the benefit of the community and the introduction of various existing socio-cultural approaches. Furthermore, to carry out revitalization, it is necessary to involve various elements such as intellectuals, the government, traditional leaders, and even community support. The involvement in question is not just participating to support aspects of formality that require community participation, besides that the people involved are not only the people in the environment but the community in a broad sense ${ }^{7}$.

In this study, the revitalization in question is how to optimize the role of local wisdom in Aceh in stemming the community from the increasingly heated influence of radicalism in Indonesia. Revitalization, which is known as an effort to strengthen back, is an ideal term when considering Aceh, which had reached the peak of its glory during the sultanate. At this time, the people of Aceh strongly adhered to their religious and cultural values so that they were united in supporting the government (sultanate) at that time.

Local wisdom is a way of life and knowledge as well as various life strategies in the form of activities carried out by local communities in responding to various problems in meeting their needs. In a foreign language, it is often conceptualized as a local policy of local wisdom or local knowledge "local knowledge" or local intelligence Fajarini's local genius ${ }^{8}$. Various strategies are carried out by the local community to maintain their culture.

Local wisdom is the identity or cultural personality of a nation that causes the nation to be able to absorb, even cultivate culture from outside/other nations into

Kearifan Lokal, Presented paper on Workshop Strategic Planning Penyelesaian Pelanggaran HAM Masa lalu di Aceh, held in Sabang on May $22^{\text {nd }}-23^{\text {rd }}, 2006$ by Aceh Judicial Monitoring Institute (AJMI).

${ }^{5}$ Abidin Nurdin, Revitalisasi..., p. 151-152.

${ }^{6}$ M. Anisworo, Revitalisasi Kawasan Kota: Sebuah Catatan dalam Pengembangan dan Pemanfaatan Kawasan Kota, (Yogyakarta: Urdi, 2002), p. 12.

${ }^{7}$ Alfianita, Ella, et al., Revitalisasi Pasar Tradisional Dalam Perspektif Good Governance (Studi di Pasar Tumpang Kabupaten Malang), (Malang: Jurusan Administrasi Publik Fakultas Ilmu Administrasi Universitas Brawijaya, 2015), p. 3.

${ }^{8}$ Atmodjo, Pengertian Kearifan Lokal Dan Relevansinya Dalam Modernisasi, (Jakarta: Dunia Pustaka Jaya, 1986), p. 45. 
its own character and abilities ${ }^{9}$. The identity and personality of course adapt to the views of the surrounding community so that there is no shift in values. Local wisdom is one of the means of cultivating culture and defending oneself from foreign cultures that are not good.

Furthermore, Istiawati views that local wisdom is the way people behave and act in response to changes in the physical and cultural environment ${ }^{10}$. A conceptual idea that lives in society grows and develops continuously in people's awareness from those related to sacred life to the profane (daily part of life and is mediocre in nature). Local wisdom can be understood as local ideas that are wise, full of wisdom, of good value, which are embedded and followed by members of the community.

Talking about local wisdom in Aceh will never be separated from the Tengku war or the ulama in it. The existence of ulama as a place to rely on the community and even leaders has been reflected since the time of the sultanate. Even when Aceh was led by the sultaniahs, it was indirectly the ulama who played a role in taking all the important policies of the kingdom. This shows that local wisdom in Aceh is a synergy between umara and ulama who focus on the welfare of the community.

Efforts to revitalize Aceh's local wisdom continue to be carried out, this is reflected in the enactment of Qanun No. 5 of 2003 concerning government Gampong which strengthens and perfects the previous qanun. The Qanun states that the gampong is the lowest government organization under settlement within the organizational structure of the Aceh Province government ${ }^{11}$. This shows that local wisdom is the foundation and important indicator for every element in Aceh not to lose its identity.

More specifically, after the signing of the MoU in Helsinki on August 15, 2005, which mandated the Law on Governing Aceh (UUPA). So after that, Law no. 11 of 2006. The law regulates customary institutions in Chapter XIII article 98. In paragraph (3) customary institutions as referred to in paragraphs (1) and (2), include; a) Aceh customary council; b) Imeum Mukim; c) Immuem chik; d) Keuchik; e) Tuha Peut; f) Lord Lapan; g) Immuem Meunasah; h) Keujreun Blang; i) Commander Lao; j) Glee handler; k) Peutua Seuneubok; l) Haria Peuka; n) Syahbandar ${ }^{12}$. Thus, local wisdom in Aceh has obtained legal recognition and is not limited to laws.

Radical speaking does not lead to a single and absolute definition, it is a discourse that has many meanings and perspectives with multiple interpretations. Radical is not always interpreted as something good, and vice versa. According to philosophers, radicals are something good and highly recommended. In this context, radical is interpreted as an earnest, determined, even thorough effort. This is in line with the meaning of philosophy for philosophers which is believed to be an attempt to think radically to its roots.

On another perspective, radicals are also understood as violence or anarchy. Demonstrators, for example, are said to be radical protesters when they damage public facilities, injure other people, and fight against security forces by involving physical contact ${ }^{13}$. It has a different meaning from radical which is understood as critical and active. A student and researcher are required to be radical in the sense of criticizing every argument so that they get an objective truth. The radicals

${ }^{9}$ F.X, Rahyono, Kearifan Budaya dalam Kata, (Jakarta: Wedatama, 2009), p. 46.

${ }^{10}$ Abidin Nurdin, loc.Cit. p. 55.

${ }^{11}$ Himpunan Undang-Undang, Keputusan Presiden, Peraturan Daerah/Qanun, Instruksi Gubernur, Edaran Gubernur Berkaitan Pelaksanaan Syari'at Islam, (Banda Aceh: Dinas Syari'at Islam, 2005), p. 206.

${ }^{12}$ Undang-Undang Republik Indonesia Tentang Pemerintahan Aceh Nomor 11 Tahun 2006 (Banda Aceh: Dinas Informasi dan Komunikasi Provinsi Nanggroe Aceh Darussalam, 2006), pp. 85-86.

${ }^{13}$ Ali Syu'aibi, Meluruskan Radikalisme Islam, (Ciputat: Pustaka Azhary, 2004), p. 8. 
Happy Saputra, Mahdalena Nasrun \& Muhammad Anzaikhan

referred to in this study are not the various definitions above. Rather, it is radical which leads to rejection or disapproval of the state or the sovereignty of a state. When radicals on this plain unite and propagate in an organization of understanding, then it will transform into radicalism. Radicalism is an understanding that requires change, replacement, and penetration of a community system to its roots. Radicalism wants a total change in a condition or all aspects of people's lives. Radicals think that the plans used are the most ideal plans. Related to this radicalism, it is often based on a narrow understanding of religion which leads to terrorist bombings growing with the system. This extreme attitude proliferates in the middle of the stage showing poverty, social inequality, or injustice ${ }^{14}$.

According to Prof. Hasbi Amiruddin, Aceh after the Moupeace Helsingki tends to be more conducive. There is not a movement or radical idealism that is clearly detected so that it can be claimed as an ideology of radicalism. The radicalism movement, according to him, was most obvious when Aceh was in conflict with the Republic of Indonesia, both in the DI-TII case and the existence of the Free Aceh Movement (GAM) ${ }^{15}$.

According to a representative from Kenbaspol Banda Aceh, radicalism was most prevalent during the conflict period, everyone agreed with that. However, if we talk about post-conflict, radicalism activities were found in Aceh after an armed terrorist network was training in the interior of Mount Seulawah. According to him, the terrorist network is an extension of the Nurdin M. Top group that once bombed Bali ${ }^{16}$.

According to him, in Aceh there are very many values of radicalism circulating, it's just that if it's still in the realm of mere thought then it's a matter of course. In fact, said Gusdur, eliminating the concept of a caliphate in a country that is actually Muslim is nonsense. It means, radical values can't be totally eradicated because it is the nature of human thinking. It's just how far the existence is actualized. When a radical concept or ideology enters the realm of implementation, it will friction with the law and will become the main enemy of the TNI and Polri as government officials in charge of their fields ${ }^{17}$.

Regarding the existence of a terrorist network in Aceh, according to Andriawan, it is the negligence of government officials who have left an empty zone without supervision in Aceh. So far, there is no mention of the community being involved, but if not, why are they holding the exercise in Aceh? This is a kind of release of the issue only so that the TNI or Polri government is separated from their duties from public control. Supposedly, elements related to terrorists in Aceh must be eradicated from the roots, lest they give birth to new terrorists who make Aceh an easy target because it has more Islamic values than other regions ${ }^{18}$.

Talking about the existence of radicalism in Aceh, Aceh is classified as an area with the smallest actions, Acehnese radicalism still exists but the quantity is lowest, it is called personal radicalism. Because the effect is not widespread, even if found or arrested, will fall on the presumption of personal crimes. This means that Aceh's radicalism has no impact on the value of terrorism. This is the role and strong influence of the Acehnese people on religious values. Phenomenologically, religion acts as an enlightenment for its adherents, in Aceh religion is very crucial, but in

\footnotetext{
${ }^{14}$ Zuly Qodir, Radikalisme Agama di Indonesia, (Yogyakarta: Pustaka Pelajar, 2014), p. 117.

${ }^{15}$ Interview with Hasbi Amiruddin in Pasca Sarjana, July 2019.

${ }^{16}$ Interview with Andriawan (pseudonym) in July 2019.

${ }^{17}$ Ibid.,

${ }^{18}$ Ibid.,
} 
my subjectivity, religious figures have a minimal role in socializing radicalism. Society is not affected by radicalism purely because of their personal understanding ${ }^{19}$.

According to Zulfata as the author of Religion and Politics (Agapol) in Aceh. The shoot of radicalism in Aceh that has not disappeared until now is the hatred of the Acehnese people towards Soekarno's political style when he made a promise to Daud Beureuh. Soekarno promised that Aceh would be given the freedom to practice Islamic law when the war was over. Based on the agreement, Aceh helped Indonesia, one of which was to provide the first plane from the proceeds of the Acehnese people's gold donation ${ }^{20}$.

Unfortunately, Sukarno later did not keep his promise. For reasons of unity, he rejected the implementation of Islamic law in any region in Indonesia. He emphasized in his speech before the people of Amuntai, South Kalimantan on January 27, 1953: "Indonesia is a national country with the ideology of Pancasila, and not a theocratic state with a certain religious orientation." As a result, Aceh experienced resistance and as a form of political accountability, in September 1953, Daud Beureuh decided to enter the forest and join DI/TII SM Kartosoewirjo as a form of disappointment with Sukarno who broke his promise ${ }^{21}$.

Even though almost half a century has passed, the disappointment of the Acehnese people has reconnected after Megawati as Soekarno's daughter took office as president of Indonesia. Instead of cooling, Aceh's radical form through GAM was met with firm resistance with the imposition of martial law on the basis of Megawati's authority. The suffering of the conflict made Aceh even more radical with Indonesia, this then ended when the SBY government through Yusuf Kala who took the path of peace with Aceh so that Aceh obtained special autonomy ${ }^{22}$.

This is the style of Aceh's radicalism in general, they still hold grudges over past history. Especially now that Jokowi's reign (two periods) is also in line with Soekarno as the figure behind Megawati's existence.

The people of Aceh hate the central government, even though now Aceh has been given the right to be an Islamic law area. Apart from the support of political opponents, the flow of radicalism in Aceh is usually not far from this narrative ${ }^{23}$.

\section{Patterns of Local Wisdom in Aceh}

1. Tengku Dayah

According to Prof. Hasbi Amiruddin, local wisdom in Banda Aceh and its surroundings lies in the role of the Tengku as a figure who is used by the community as a place to ask questions. Tengku is the last bastion of ideological and axiological filtering. According to the results of his research, Prof. Hasbi once interviewed several individuals who were involved with recruiting GAM members during the conflict period. As understood, GAM or the so-called Free Aceh Movement is a government opposition movement that seeks to fight for Aceh to separate from the Republic of Indonesia ${ }^{24}$.

At that time, a young man with a casual job was offered to become a GAM soldier. He was promised to be given shopping money, cigarette money, and wealth when he succeeded in becoming independent. Before deciding to join, he met his study center first. That there is an offer that is considered profitable because it has

\footnotetext{
${ }^{19}$ Interview with Iping Rahmat Saputra in July 2019.

${ }^{20}$ Interview with Zulfata in July 2019.

${ }^{21}$ Ibid.,

${ }^{22}$ Ibid.,

${ }^{23}$ Ibid.,

${ }^{24}$ Hasbi Amiruddin, Loc.Cit.,
} 
Happy Saputra, Mahdalena Nasrun \& Muhammad Anzaikhan

a steady income from a job that was not clear before. Then, his neck recited a verse from the Quran which means; "Killing each other between Muslims, both will go to hell." Tengku also advises; "Let the work is not clear (mocok-mocok) but lawful than killing Muslims which is clearly forbidden." After listening to his teacher's advice, the young man decided not to join GAM as a radical movement against the existence of the Indonesian state ${ }^{25}$.

\section{Meuseuraya}

Meuseuraya is used by Acehnese to refer to an activity that is a general characteristic of the Indonesian people, mutual cooperation. On the one hand, this tradition is only easy to find in villages. In some places close to cities such as Banda Aceh, this tradition can still be found. Even though it is not as strong as the villages, which are still stronger with the spirit of togetherness ${ }^{26}$. Actually there is no difference between gotong-royong and meuseraya, only the way of talking about it is acculturated to Acehnese customs.

Meuseuraya is Aceh's local wisdom which is quite effective in countering radicalism in Aceh. As far as observations so far, people who are involved in routine gotong royong will have an active and communicative social relationship with the community. Usually, Acehnese who likes meuseuraya will also actively pray in the congregation at the mosque or prayer room. Through a social environment like this, usually people will avoid the values of radicalism brought by a handful of people. When there are seeds of radicalism, society will protect them and remember and take care of each other.

\section{Madja}

Hadih maja can be defined as sayings or proverbs in the life of the Acehnese people that contain philosophical elements that are used as advice, warnings, explanations, parables, even subtle satire that are used as guidelines in living social life in Aceh $^{27}$. This method is considered polite because it can advise someone without hurting him. Such culture is considered to be less popular, especially among Acehnese millennials today.

The local wisdom contained in hadih maja is an accumulation of knowledge and wisdom that grows and develops in a community that represents its theological, cosmological, and sociological perspectives. Efforts to build the character of the young generation of Aceh based on hadih maja from an early age through education are considered the right step ${ }^{28}$. It can be said that Hadih Madjasolutive is amedium in bridging the problems in Aceh, including being a solution in countering radicalism.

\section{Peusijuekflouring}

PeusijuekTawari (Acehnese language) is one of the Acehnese traditions that is still preserved today. Peusijuek is known as part of the Acehnese customs. Peusijuek in language comes from the word sijuek (Acehnese which means cold), then add the prefix peu (making things), which means to make something so cool, or refrigerate ${ }^{29}$.

${ }^{25}$ Ibid.,

${ }^{26}$ Syamsuddin and Otto Ishak, Reintegrasi: Pelaksanaan dan Permasalahannya, (Banda Aceh: Achehnese Civil Society Task Force, 2009), p. 43.

${ }^{27}$ Muhammad Harun, et al., Revitalisasi Nilai Etos Kerja dalam Hadih Madja Sebagai Bahan Ajar Pendidikan Karakter, Jurnal of East, Vol. 1, No. 3, 2015, p. 55.

${ }^{28}$ Ibid. p. 6.

${ }^{29}$ Marzuki, Tradisi Peusijeuk dalam Masyarakat Aceh, (Banda Aceh, ICIAOS, 2011), p. 53. 
This custom is one of the local wisdom in Aceh that comes from Hindu culture which is Islamized. This tradition is usually done to ask for safety, peace, and happiness in life. The Peusijuek tradition is a tradition that has existed since ancient times and is still often practiced today. This tradition is usually carried out in almost all traditional Acehnese activities, such as traditional weddings, traditional celebrations, thanksgiving, and other traditional ceremonies ${ }^{30}$.

Similar to the meuseuraya above, the ritual peseujukhas contributed to counteracting the potential for radicalism that has entered Aceh through prayer intermediaries. In addition to being oriented to the spiritual realm, when the prayer leader gives lectures, he often advises on maintaining brotherhood and the unitary state of the Republic of Indonesia. Through this momentum, more or less can filter the Acehnese people from the influence of radicalism.

\section{The Role of District and Border Da'i}

The local wisdom of Aceh, especially in the Tamiang area, to prevent radicalism is to optimize the function of the District Da'i and Border Da'i. As is well known, this da'i is a local government program that has existed since the previous administration period. This is a form of political contract between the PKS party and the elected regent. Moreover, at this time, the deputy regent of Aceh Tamiang is a stretcher of PKS, so this program continues to expand the message of da'wah. Through this Da'I, it becomes a filter for the values of radicalism that are trying to enter Aceh Tamiang ${ }^{31}$.

When radical issues come in, through a guided mechanism, the Da'i will inform all corners of Aceh Tamiang to remain united and uphold the state ideology, namely Pancasila. However, in practice, not all preachers understand the nature of nationalism. There are still many Da'I who are not filtered but are carriers of radicalism teachings and values. For example, those who are too fanatical about Islam will carry the black flag attribute (HTI) which is legally prohibited.

\section{Closing}

Radicalism is very dangerous, so it is necessary to try to protect it in such a way, one of which is through a cultural approach (local wisdom). This aspect is considered ideal because the character of the Acehnese is more obedient and obedient when following the authority of the ulama (tengku) and the advice of traditional leaders. In addition, through local wisdom that exists indirectly, the government through representatives of 'gampong' officials can coordinate any community members who have potential or radical seeds. It is very important to revitalize local wisdom in Aceh to protect themselves from the influence of radical ideologies. Local culture greatly influences and preserves religious solidarity in Aceh. The culture of gotongroyong, for example, is a routine community activity that is often carried out on Sundays, or on commemorations of welcoming big days such as the month of Ramadan, Eid, the Prophet's birthday, and other agendas. In addition, the culture of gotong-royong is also implemented in community social activities such as wedding ceremonies, circumcision of the apostles, and even prayer events when someone in the community dies.

Through mutual cooperation, harmony among others is created by itself. People will get to know each other so that they can both maintain the disharmony of religious communities. In addition to mutual cooperation, the culture of glorifying

\footnotetext{
${ }^{30}$ Badruzzaman Ismail, Mesjid dan Adat Meunasah sebagai Sumber Energi Budaya Aceh, (Banda Aceh: Gua Hira, 2003), p. 101.

${ }^{31}$ Interview with Husni Mubarak (Political activist in Aceh Tamiang), in July 2019.
} 
Happy Saputra, Mahdalena Nasrun \& Muhammad Anzaikhan

the ulama has also existed in Aceh for a long time. The application of ulama as traditional leaders and religious leaders has existed since the days of the ancient Aceh kingdom. The people of Aceh are very aware of the authority of the ulama, even more so than the authority of the government. The practice of cultural values has a significant impact on the socio-religious changes of the Acehnese people. Through the philosophical messages contained in the hadith madja, Acehnese people have a considerable aspect so that culture from outside is very difficult and develops in Aceh. In this section, Aceh is very intolerant of outside cultures and ideologies. This also then made Aceh tend to be apathetic towards the radical movement that entered Aceh.

\section{BIBLIOGRAPHY}

A. Hasjmy, et al, 50 Years of Aceh Building, Medan: NAD Province MUI, 1995.

Ali Syu'aibi, Straightening Islamic Radicalism, Ciputat: Pustaka Azhary, 2004.

Alfianita, Ella, et al, Revitalizing Traditional Markets in Good Governance Perspective (Study at the Tumpang Market, Malang Regency), Malang: Department of Public Administration, Faculty of Administrative Sciences, Universitas Brawijaya, 2015.

Atmodjo, Understanding Local Wisdom and Its Relevance in Modernization, Jakarta: Dunia Pustaka Jaya, 1986.

Badruzzaman Ismail, Mosques Meunasahand Customs as Sources of Cultural Energy Aceh, Banda Aceh: Hira Cave, 2003.

Collection of Laws, Presidential Decrees, Regulations Regional/Qanun, Governor's Instructions, Governor's Circular Regarding the Implementation of Islamic Shari'ah, Banda Aceh: Office of Shari'at Islam, 2005.

C. Van Dijk, Rebellion Under the Banner of Islam: The Darul Islam in Indonesia, The Hague: Martinus Nijhoff, 1981.

FX, Rahyono, Cultural Wisdom in Words, Jakarta: Wedatama, 2009.

Law of the Republic of Indonesia concerning the Government of Aceh Number 11 of 2006. Banda Aceh: Information and Communication Service of the Province of Nanggroe Aceh Darussalam, 2006.

M. Anisworo, Revitalization of Urban Areas: A Note on Urban Area Development and Utilization, Yogyakarta: Urdi, 2002.

Marzuki, Tradition Peusijeuk in Acehnese Society, Banda Aceh, ICIAOS, 2011.

Muhammad Harun, et al, "Revitalizing the Value of the Work Ethic in Hadih Madja as Character Education Teaching Materials", Journal of the East, Vol. 1, No. 3, 2015.

Muslim Ibrahim, Steps for the Implementation of Islamic Sharia in Aceh in Lahmuddin Nasution (et. al.), The Implementation of Islamic Sharia in Indonesia: Between Opportunities and Challenges. Jakarta: Globalmedia Cipta Publishing, 2004.

Patterns for Resolving Human Rights Violations: Traditional Approaches as Aspects of Local Wisdom, Paper Presented at the Workshop on Strategic Planning for the Resolution of Past Human Rights Violations in Aceh, held in Sabang on 22nd_ 23 $3^{\text {rd }}$ of May 2006 by the Aceh Judicial Monitoring Institute (AJMI). 
Revitalizing Local Wisdom in Committing Radicalism in Aceh

PKPM Research Team, Application of Alternative Dispute Resolution Based on Customary Law at the institution Keujreun Blangin Aceh Besar District. Banda Aceh: BRR Sarpras Law with PKPM, 2007.Syamsuddin and Otto Ishak, Reintegration: Implementation and Problems, Banda Aceh: Achehnese Civil Society Task Force, 2009.

Zuly Qodir, Religious Radicalism in Indonesia, Yogyakarta: Student Library, 2014 